7. Зейдер Н.Б. Судебное решение по гражданскому делу. Москва : Юрид. лит., 1966. 190 с.

8. Коршунов Н.М. Гражданский процесс: учеб. Н.М. Коршунов, Ю.Л. Мареев. Под общ. ред. Н.М. Коршунова. Москва : Изд-во «Эксмо», 2005. 800 с.

9. Штефан М.Й. Цивільне процесуальне право України : Академічний курс: підруч. для студ. юрид. спец. вищ. навч. закл. Київ : Вид. дім «Ін Юре», 2005. 624 с.

10.Постанова Верховного Суду України від 23 вересня 2015 року № 6-274цс15. URL: https://protocol.ua/ru/postanova_vsu_vid_23_09_2015_roku_u_spravi_6_274tss15/.

\title{
CMITHX A. B.,
} доктор юридичних наук, професор кафедри адміністративного та господарського права (Одеський національний університет імені I. I. Мечникова)

\section{ЩОДО УЗУФРУКТУ КОРПОРАТИВНИХ ПАЇВ (ЧАСТОК, АКЦЙ)}

Відштовхуючись від розуміння корпоративного паю (частки, акції) як оборотоздатного символу, що посвідчує корпоративні права, є безтілесним майном та об'єктом речових прав, у статті розглядається можливість визнання і закріплення у правовій системі України узуфрукту корпоративного паю (частки, акції). На відміну від сервітуту, суперфіцію та емфітевзису, які завжди встановлюються щодо нерухомого майна, узуфрукт може розглядатися як універсальна правова конструкція, що застосовується до будь-якого індивідуально-визначеного майна, яке $є$ джерелом доходу. Закріплення узуфрукту корпоративного паю (частки, акції) у правовій системі України дозволить спрямовувати дохід від корпоративного паю (частки, акції) на користь третьої особи без передачі їй права власності; оптимізувати податкові відносини щодо корпоративного паю (частки, акції) й управління майном неповнолітніх або передачу корпоративного паю (частки, акції) неповнолітнім спадкоємцям; оформлювати передачу корпоративних паїв (часток, акцій) в оплатне управління. Так само як речове право власності на корпоративний пай (частку, акцію) є підставою для виникнення корпоративних прав щодо товариства, речове право узуфрукту на корпоративний пай (частку, акцію) становитиме підставу для строкового переходу корпоративних прав до третьої особи - фруктуарія. Встановлення узуфрукту на корпоративний пай (частку, акцію) може передбачатися заповітом (заповідальним відказом), договором (зокрема під відкладальною чи скасувальною умовою), у т. ч. положеннями корпоративних договорів (договорів між акціонерами). Узуфрукт на корпоративні паї (частки, акції) повинен реєструватися: у депозитарній системі (якщо йдеться про акції); у Єдиному державному реєстрі юридичних осіб, фізичних осіб - підприємців і громадських формувань (якщо йдеться про корпоративні паї (частки), неоформлені як цінні папери).

Ключові слова: узуфрукт, корпоративний пай, акція, частка у статутному капіталі, речові права, корпоративні права.

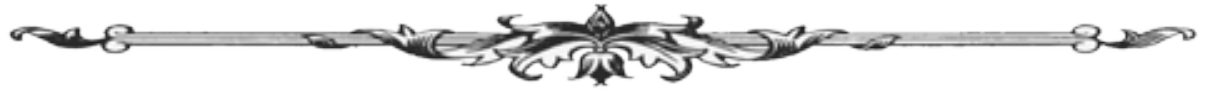


Smitiukh A. V. On the usufruct of the corporate shares (stocks)

The possibility of the implementation of the usufruct of the corporate shares (stocks) in the legal system of Ukraine is considered in the article. It is based on the understanding of the corporate share (stock) as a transferrable symbol certifying corporate rights and a disembodied property able to be under the rights in rem. Unlike easement, superficies and emphyteusis established in respect of the real estate only, the usufruct can be considered as a universal legal institiute that can be applied to any specific piece of property that is able to be a source of the revenue. The reception of the usufruct of a corporate share (stock) in the legal system of Ukraine may allow to pay a corporate share (stock) revenue in favor of a third party without transferring ownership for the corporate share (stock), to optimize tax relations on a corporate share (stock) and property management of minors as well as a transfer of a corporate share (stock) to a minor heir and finally to arrange a management of a corporate share (stock) on a paid basis. Just as the ownership right for a corporate share (stock) being right in rem is a basis for the occurrence of the corporate rights for the company, usufruct right in rem of the corporate share (stock) is a basis for a transfer of corporate rights to a third party named fructuary for a certain period of time. Establishment of an usufruct of a corporate share (stock) may be provided by a will (testamentary renunication or legatum). It may be established also by an agreement (in particular under a suspensive or revocation condition) namely - by the special clause of the corporate agreement (shareholders agreement).

Usufruct of a corporate share (stock) must be subjected to the obligatory registration as a right in rem. The usufruct of the stocks issued by the joint-stock company is to be enetered in the depository system. At the same time usufruct for the rest of the corporate shares not issued as securities may be registered in the Unified State Register of Legal Entities, Individuals - Entrepreneurs and Public Associations.

Ключові слова: иsufruct, corporate share, stock, share in the authorized capital, rights in rem, corporate rights.

Вступ. Одним із результатів кодифікації цивільного права, яка завершилася прийняттям Цивільного кодексу України у 2004 р., стала рецепція до правової системи України таких класичних римських речових прав на чуже майно, як сервітут, емфітевзис, суперфіцій, але не узуфрукт (лат. - usus fructus), який Павло визначив як «право користуватися чужими речами й отримувати їхні плоди зі збереженням субстанції речей цілісною» (Павло, D. $7,1,1[1$, c. 283$])$.

Водночас інститут узуфрукту став складовою частиною багатьох правових систем континентальної правової сім'ї (зокрема Бельгії, Іспанії, Італії, Квебеку, Нідерландів, Німеччини, Франції, Швейцарії, Туреччини), у т. ч. постсоціалістичних (Болгарії, Польщі, Румунії, Угорщини, Чехії) та деяких пострадянських (Естонії, Молдови) країн. Слід відзначити, що деякі дослідники називають узуфрукт «другим серед речових прав за значущістю після права власності» [2, с. 140] й «еталоном права користування чужим майном» [3, с. 189].

Вихідна ідея узуфрукту із часом творчо переосмислюється і розвивається, причому цей розвиток відбувається у різних правових системах по-різному [4, с. 64]. Якщо у Давньому Римі та під час перших європейських кодифікацій у Франції та Німеччині узуфрукт розуміли як право лише на тілесну річ (jus in corpore), зі зникненням якої узуфрукт припинявся (Цельс, D. 7,1,2 [1, с. 283]), а сфера реалізації узуфрукту вбачалася виключно у сімейних і спадкових відносинах (Р. Ієринг наприкінці XIX ст. пропонував премію тому, хто наведе приклад реального використання узуфрукту поза колом сімейних відносин, оскільки той «абсолютно не потрібен для цивільного обороту. Його місце проживання - сім'я, домашне коло, яке він майже ніколи не покидає, щоб вийти на вулицю; поза сімейним колом він існує тільки в підручниках» [5, с. 14]), то на початку XXI ст. у Франції узуфрукт встановлюється на

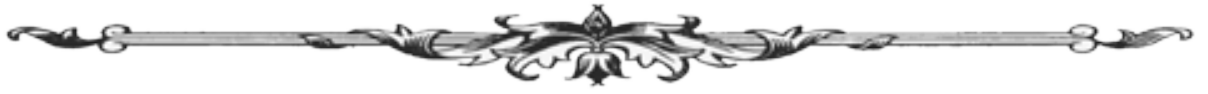


рухоме та нерухоме майно, безтілесні речі (зокрема майнові права, об'єкти права інтелектуальної власності), у Німеччині узуфрукт використовується у підприємницькому, торговому, комп'ютерному праві, відповідно об'єктами узуфрукту стають частки у спільній власності, комп'ютерні програми, цілісні майнові комплекси, цінні папери (у т.ч. акції) [6, с. 377-378], а у світовій практиці - будь-які тілесні та безтілесні об’єкти, що здатні приносити економічну вигоду [3, с. 193]. Такий підхід до узуфрукту є домінуючим, навпаки, обмеження кола об’єктів узуфрукту нерухомістю (ст. 296 ЦК Польщі [7], проект змін до ЦК РФ [8]) і пряма заборона використання узуфрукту у підприємницькій діяльності (проект змін до ЦК РФ [8]) слід розглядати швидше як виняток із правила [9, с. 56, 57].

Корпоративний пай (у т. ч. частка у статутному капіталі, акція) є об'єктом речового права власності, отже можна ставити питання про визнання щодо цього об'єкту інших речових праву. Специфіка корпоративного паю (частки, акції) виключає встановлення щодо нього таких класичних речових прав як сервітут, суперфіцій та емфітевзис, які завжди встановлюються щодо нерухомого майна, проте узуфрукт може розглядатися як універсальна правова конструкція, що може застосовуватися до будь-якого індивідуально-визначеного майна, яке є джерелом доходу.

У деяких правових системах можливість узуфрукту корпоративних паїв прямо врегульована чинним законодавством, що ставить питання про доцільність закріплення узуфрукту корпоративних паїв у правовій системі України.

Проблематику узуфрукту досліджували Б.О. Антонов, Н.В. Безік, Л.Ю. Василевська, С.О. Громов, І.О. Ємелькіна, Д.В. Лоренц, В.С. Карнушин, Г.С. Мацакян, Т.О. Мечетіна, Г.Ю. Міцик, І.В. Сіваракша, О.Г. Сіроткін, О.Р. Сухарева, проте узуфрукт корпоративних паїв не ставав ще предметом окремого дослідження.

Постановка завдання. Мета статті полягає у тому, щоб розв'язати питання про доцільність впровадження (рецепції) інституту узуфрукту корпоративних паїв до правової системи України та визначити засади, відповідно до яких таке впровадження (рецепція) може відбуватися.

Результати дослідження. Узуфрукт корпоративних паїв прямо передбачений спеціальними нормами законодавства таких країн, як Бельгія (ст. 5:22, 6:22, 7:26 Кодексу товариств та об’єднань Бельгії щодо АТ, ТОВ і кооперативів [10]), Нідерланди (ст. 2:88, 2:197 ЦК Нідерландів щодо відритих і закритих корпорацій [11]), Туреччина (ст. 60 ГК Туреччини щодо ТОВ [12, с. 279]), Франція (ст. 1844, 1844-5 ЦК Франції [13], ст. L225110, L225-118, L225-140 ГК Франції щодо ТОВ та АТ [14]), Швейцарія (ст. 6861H, 789aA ЦК Швейцарії щодо АТ і ТОВ [15]), у Німеччині така можливість визнається у доктрині та судовій практиці [6, с. 378]. Найбільш повним є регулювання цих відносин у правових системах Нідерландів і Франції.

Слід відзначити, що, крім спеціальних норм про узуфрукт корпоративних паїв (акцій, часток), наведені вище правові системи містять загальні норми про узуфрукт, отже, оскільки узуфрукт корпоративного паю є окремим випадком узуфрукту як такого, впровадження до правової системи України узуфрукту корпоративного паю доцільно здійснювати одночасно із закріпленням у законодавстві загальних норм про узуфрукт. 3 іншого боку, «авангардне» впровадження сукупності норм, здатних повною мірою врегулювати всі аспекти узуфрукту корпоративного паю, може стимулювати прийняття згодом загальних норм про узуфрукт, що регулюватимуть відносини щодо інших об'єктів (нерухоме та рухоме майно, цінні папери, відмінні від акцій та ін.).

Основою узуфрукту є встановлений відповідно до закону, договору чи за прямою вказівкою закону функціональний розподіл речових повноважень власності, за якого фруктуарій отримує на певний строк (у т. ч. на весь час життя або до настання скасувальної обставини) право найбільш повним чином використовувати майно, тобто отримувати усі його плоди, а власник має титул «голого власника» (у правовій системі Франції), тобто власника без права користування майном (у правовій системі Німеччини таке право власності також вважається дефектним) [6, с. 376].

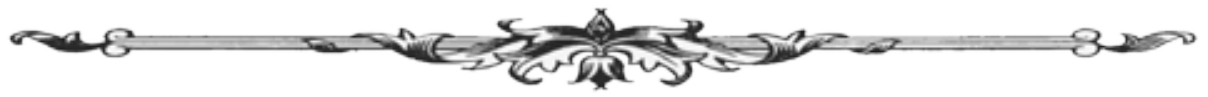


Узуфрукт може встановлюватися, серед іншого, для забезпечення певної особи доходом від певного майна, для перерозподілу податкового тягаря між членами сім'ї (оскільки податки, пов'язані з майном, сплачує фруктуарій, який отримує плоди) [6, с. 378; 3, с. 199] або виступати альтернативою найму [6, с. 381].

У корпоративно-правовому контексті узуфрукт є правовою конструкцією, здатною розв'язати нарешті проблему неподільності комплексу корпоративних прав.

Деякі дослідники, зокрема, В. Бірюков і В.М. Кравчук [16, с. 26; 17, с. 11] відстоюють можливість поділу корпоративних прав. В.М. Кравчук зауважує, що окремі корпоративні права (не лише майнові права, наприклад право на дивіденди, але й правомочності немайнового характеру, зокрема право голосувати на загальних зборах) можуть відчужуватися самостійно, як окремі оборотоздатні об'єкти [17, с. 11].

Проте такий підхід видається несумісним із визнанням існування корпоративного паю, який, по суті, представляє сукупність корпоративних прав в обороті як транзитивний знак (символічний об’єкт) і виступає предметом всіх правочинів, що укладаються з метою набуття корпоративних прав щодо певної юридичної особи корпоративного типу (далі - товариство).

Відчуження окремого корпоративного права чи окремої правомочності, яка входить до складу суб' єктивного корпоративного права вищого рівня (правомочність голосувати на загальних зборах як складова частина права брати участь в управлінні товариством) означає кінцеву й остаточну втрату зв'язку між учасником і такою правомочністю: суб' єктом окремої корпоративної правомочності за такого сценарію назавжди стає особа, котра не $є$ ані учасником відповідного товариства, ані власником корпоративного паю, навіть більше - така особа може відчужити належну їй окрему корпоративну правомочність іншій, третій особі. Так само цей підхід уможливлює ситуацію, за якої учасник товариства може «розпродати» окремі суб’ єктивні корпоративні права, що випливають з одного корпоративного паю різним особам. Визнання зазначених вище можливостей повністю руйнує концептуальні засади суб'єктивних корпоративних прав і може приводити до негативних наслідків на практиці.

Навпаки, впровадження узуфрукту корпоративного паю дозволяє його власнику наділити третю особу корпоративними правами на строковій (відповідно, поворотній) $i$, можливо, оплатній основі через конструкцію речового права на чужу річ, якою є безтілесне майно, цифровий об'єкт - корпоративний пай.

Основна тріада правомочностей власника тілесної речі, яку, попри ії обмеженість, включає, як відомо, правомочності володіння (jus possidendi), користування (jus utendi / fruendi) та розпорядження (jus disponendi). Проте у випадку з корпоративними паями, що існують у вигляді електронних записів, які обліковуються у певних системах і на непідконтрольних власникові носіях і є безтілесним майном (цифровими об'єктами), правомочність володіння як фактичного панування над річчю [18, с. 360] значною мірою втрачає сенс, а правомочність користування корпоративним паєм як можливості вилучення його корисних властивостей $[19$, с. 55] (цивільних плодів, тобто - грошових виплат) розкривається фактично через зміст принаймні деяких засвідчених ним корпоративних прав. Таким чином, узуфрукт корпоративного паю утворюватиме речово-правову підставу переходу до фруктуарія корпоративних прав на певний строк (можливо - на строк життя фруктуарія) на оплатній або безоплатній основі (обсяг корпоративних прав, що переходять до фруктуарія внаслідок узуфрукту корпоративного паю, має бути предметом окремого дослідження), подальше відчуження корпоративного паю власником на користь третьої особи упродовж строку дії узуфрукту не припинятиме його.

Слід підкреслити, що власник корпоративного паю, щодо якого встановлений узуфрукт, зберігає статус учасника товариства, а особа, на користь якої встановлений узуфрукт, отримує особливий, відмінний як від статусу власника корпоративного паю, так і від статусу учасника товариства правовий статус фруктуарія (користоволодільця), котрий дозволяе отримувати грошові надходження, пов'язані з корпоративним паєм, тобто дивіденди, майнову корпоративну квоту і, відповідно, здійснювати певні корпоративні права та пов'язані 3 ними зобов'язальні права корпоративного походження щодо відповідного товариства протягом строку дії узуфрукту. Так само як речове право власності на корпоративний пай $є$ під-

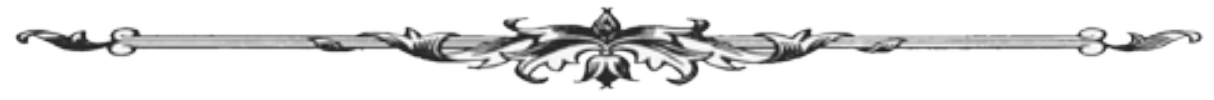


ставою для виникнення статусу учасника товариства та корпоративних прав щодо нього, речове право узуфрукту на корпоративний пай становитиме підставу для строкового переходу корпоративних прав до третьої особи - фруктуарія.

Узуфрукт корпоративного паю може виступати альтернативою його оренді: ст. 239-3 ГК Франції прямо встановлює, що орендар частки отримує права фруктуарія частки, а орендодавець має статус іiі «голого власника» [14], тобто фактично застосовує до оренди частки модель узуфруктного розподілу правомочностей, які становлять коло корпоративних прав, а дослідники французької моделі узуфрукту підкреслюють незначну, зникаючу різницю між узуфруктом та орендою, віддаючи перевагу узуфрукту [2, с. 138].

Іноземний досвід правового регулювання підтверджує можливість узуфрукту корпоративного паю, що дозволяє вирішувати низку практичних питань. Насамперед це спрямовування доходу від корпоративного паю на користь третьої особи без передачі їй права власності (як зауважують деякі дослідники, узуфрукт пов'язаний «із забезпеченням соціальних інтересів осіб, що мають право на утримання» [9, с. 57]). Проте узуфрукт, як вже зазначалося вище, дозволяє оптимізувати податкові відносини й управління майном неповнолітніх або передачу корпоративного паю неповнолітнім спадкоємцям (наприклад, онука спадкує за заповітом належні дідові корпоративні паї й отримує їх у власність, водночас її батько (син діда) отримує за заповідальним відказом узуфрукт до досягнення спадкоємицею повноліття із тим, що управляти корпоративними паями та нести тягар сплати пов'язаних із ними податків, так само батько може подарувати корпоративні паї дітям зі збереженням за собою узуфрукту до досягнення ними повноліття 3 тією самою метою [6, с. 381]). Нарешті, узуфрукт корпоративних паїв має значний потенціал використання поза контекстом сімейно-спадкової проблематики: саме заснованим на договорі узуфруктом можна оформлювати передачу корпоративних паїв в оплатне управління, коли фруктуарій сплачує власникові корпоративних паїв певну винагороду: регулярні виплати lump sum (аналог орендної плати) або ж відсоток від дивідендів.

Також встановлення узуфрукту на корпоративні паї (зокрема під відкладальною чи скасувальною умовою) може бути передбачене положеннями корпоративних договорів (договорів між акціонерами) та складати частину домовленості учасників (акціонерів) щодо порядку реалізації ними корпоративних прав.

Таким чином, узуфрукт як речове право щодо корпоративного паю має бути визнаний і закріплений у правовій системі України так само, як мають бути визнані право господарського відання на корпоративний пай, право довірчої власності на корпоративний пай і право користування (оренди) корпоративним паєм.

Узуфрукт, як і усі інші речові права на чужі корпоративні паї, повинен реєструватися: узуфрукт щодо акцій - у депозитарній системі; узуфрукт щодо корпоративних паїв, неоформлених як цінні папери - у Сдиному державному реєстрі юридичних осіб, фізичних осіб - підприємців і громадських формувань.

Висновки. Проведене дослідження дозволило сформулювати такі положення:

1. Узуфрукт корпоративного паю (частки, акції) доцільно закріпити у правовій системі України.

2. Власник корпоративного паю, щодо якого встановлений узуфрукт, зберігатиме статус учасника товариства, а особа, на користь якої встановлений узуфрукт, отримуватиме особливий, відмінний як від статусу власника корпоративного паю, так і від статусу учасника товариства правовий статус фруктуарію, що дозволятиме отримувати грошові надходження, пов’язані з корпоративним паєм, тобто дивіденди, майнову корпоративну квоту і, відповідно, здійснювати на оплатній чи безоплатній основі певні корпоративні права та пов'язані з ними зобов’язальні права корпоративного походження щодо відповідного товариства протягом строку дії узуфрукту (обсяг корпоративних прав, які переходять до фруктуарія внаслідок узуфрукту корпоративного паю, має бути предметом окремого дослідження). Так само, як речове право власності на корпоративний пай $є$ підставою для виникнення статусу учасника товариства та корпоративних прав щодо нього, речове право узуфрукту на корпоративний

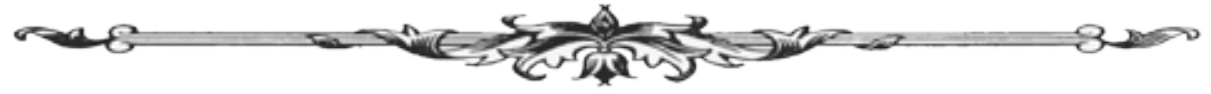


пай становитиме підставу для строкового переходу корпоративних прав до третьої особи фруктуарія.

3. Закріплення узуфрукту корпоративного паю у правовій системі України дозволить: спрямовувати дохід від корпоративного паю на користь третьої особи без передачі їй права власності; оптимізовувати податкові відносини щодо корпоративного паю та управління майном неповнолітніх або передачу корпоративного паю неповнолітнім спадкоємцям; оформлювати передачу корпоративних паїв в оплатне управління.

4. Встановлення узуфрукту на корпоративні паї може передбачатися заповітом (заповідальним відказом), договором (зокрема під відкладальною чи скасувальною умовою), У т. ч. положеннями корпоративних договорів (договорів між акціонерами).

5. Узуфрукт на корпоративні паї повинен реєструватися: у депозитарній системі (якщо йдеться про акції); у Єдиному державному реєстрі юридичних осіб, фізичних осіб підприємців і громадських формувань (якщо йдеться про корпоративні паї, не оформлені як цінні папери).

\section{Список використаних джерел:}

1. Дигесты Юстиниана. Памятники римского права: Законы XII таблиц. Институиии Гая. Дигесты Юстиниана. Москва : Зерцало, 1997. С. 152-598.

2. Сиваракша И.В. Сервитуты и узуфрукт в Гражданском кодексе Франции 1804 года : дис. ... канд. юрид. наук : 12.00 .01 : Москва, 2000154 с.

3. Громов С.А. Узуфрукт: юридическая конструкция и вещное право. Вещные права: постановка проблемы и её решение. Москва : Статут, 2011. С. 188-231.

4. Мацакян Г.Р. Особенности правовой конструкции узуфрукта в российском, германском и французском гражданском праве. Юридическая наука. 2016. № 2. С. 58-65.

5. Иеринг Р. Теория владения. Санкт-Петербург : Изд-во Н.К. Мартынова, 1895. 48 с.

6. Антонов Б.А. Формирование института узуфрукта в германском гражданском праве : дис. ... канд. юрид. наук : 12.00 .01 Москва, 2006242 с.

7. Kodeks cywilny Rzeczypospolitej Polskiej. URL: http://prawo.sejm.gov.pl/isap.nsf/ download.xsp/WDU19640160093/U/D19640093Lj.pdf.

8. О внесении изменений в части первую, вторую, третью и четвертую Гражданского кодекса Российской Федерации, а также в отельные законодательные акты Российской Федерации : Проект Федерального Закона № 47538-6. URL: https://sozd.duma.gov.ru/bill/47538-6.

9. Лоренц Д.В. Право личного пользовладения (узуфрукт): перспективы в России и опыт зарубежных стран. Вестник Южно-Уральского государственного университета. Серия «Право». 2013. Т. 13. № 2. С. 55-58.

10. Code des sociétés et des associations. URL: http://www.ejustice.just.fgov.be/eli/ loi/2019/03/23/2019A40586/justel.

11. Civil Code of the Netherlands. URL: http://www.dutchcivillaw. com/civilcodegeneral.htm.

12. Turkish Commercial Code. Türk Ticaret Kanunu. Istanbul : Vedat Kitapçilik, 2017. 728 p.

13. Civil Code of France. URL: https://www.legifrance.gouv.fr/content/download/1950/ 13681/version/3/file/Code_22.pdf.

14. Commercial Code of France. URL: https://www.legifrance.gouv.fr/Media/Traductions/ English-en/code_commerce_part_L_EN_20130701.

15. Federal Act on the Amendment of the Swiss Civil Code (PartFive: The Code ofObligations) of 30 March 1911. URL: https://www.admin.ch/opc/ en/classified-compilation/19110009.

16. Бірюков В. Аналіз деяких спірних питань корпоративних відносин. Право Украӥни. 2011. № 8. C. 24-28.

17. Кравчук В.М. Припинення корпоративних правовідносин в господарських товариствах : автореф. дис. ... докт. юрид. наук : 12.00.03. Харків, 2010. 38 с.

18.Дождев Д.В. Римское частное право : учебник. Москва : ИНФРА-М-НОРМА, 1999. $784 \mathrm{c}$.

19. Камышанский В.П. Право собственности: пределы и ограничения. Москва : ЮНИТИ-ДАТА. Закон и право, 2000. 303 с.

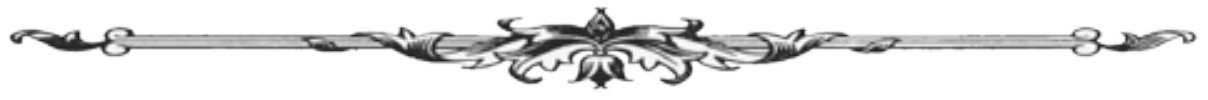

